\title{
Sarcopenia in Autoimmune and Rheumatic Diseases: A Comprehensive Review
}

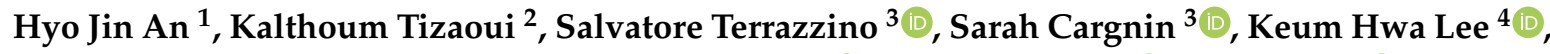 \\ Seoung Wan Nam ${ }^{5}$, Jae Seok Kim ${ }^{6}$, Jae Won Yang ${ }^{6}{ }^{(D}$, Jun Young Lee ${ }^{6}\left(\mathbb{D}\right.$, Lee Smith ${ }^{7}$,

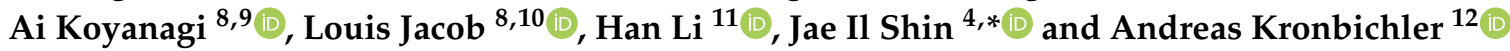 \\ 1 Yonsei University College of Medicine, Seoul 03722, Korea; hjj622@yonsei.ac.kr \\ 2 Laboratory Microorganismes and Active Biomolecules, Sciences Faculty of Tunis, University Tunis El Manar, \\ Tunis 2092, Tunisia; kalttizaoui@gmail.com \\ 3 Department of Pharmaceutical Sciences and Interdepartmental Research Center of Pharmacogenetics and \\ Pharmacogenomics (CRIFF), University of Piemonte Orientale, 28100 Novara, Italy; \\ salvatore.terrazzino@uniupo.it (S.T.); sarah.cargnin@uniupo.it (S.C.) \\ 4 Department of Pediatrics, Yonsei University College of Medicine, Seoul 03722, Korea; AZSAGM@yuhs.ac \\ 5 Department of Rheumatology, Wonju Severance Christian Hospital, Yonsei University Wonju College of \\ Medicine, Wonju 26426, Korea; namsw@yonsei.ac.kr \\ 6 Department of Nephrology, Yonsei University Wonju College of Medicine, Wonju 26426, Korea; \\ ripplesong@yonsei.ac.kr (J.S.K.); kidney74@yonsei.ac.kr (J.W.Y.); junyoung07@yonsei.ac.kr (J.Y.L.) \\ 7 The Cambridge Centre for Sport and Exercise Science, Anglia Ruskin University, Cambridge CB1 1PT, UK; \\ Lee.Smith@anglia.ac.uk \\ 8 Research and Development Unit, Parc Sanitari Sant Joan de Déu, CIBERSAM, 08830 Barcelona, Spain; \\ a.koyanagi@pssjd.org (A.K.); louis.jacob.contacts@gmail.com (L.J.) \\ 9 ICREA, Pg. Lluis Companys 23, 08010 Barcelona, Spain \\ 10 Faculty of Medicine, University of Versailles Saint-Quentin-en-Yvelines, 78000 Versailles, France \\ 11 University of Florida College of Medicine, Gainesville, FL 32610, USA; lih2@ufl.edu \\ 12 Department of Internal Medicine IV (Nephrology and Hypertension), Medical University Innsbruck, \\ 6020 Innsbruck, Austria; Andreas.Kronbichler@i-med.ac.at \\ * Correspondence: SHINJI@yuhs.ac; Tel.: +82-2-22282-050
}

Received: 9 July 2020; Accepted: 3 August 2020; Published: 7 August 2020

\begin{abstract}
Sarcopenia refers to a decrease in skeletal muscle mass and function. Because sarcopenia affects mortality, and causes significant disability, the clinical importance of sarcopenia is emerging. At first, sarcopenia was recognized as an age-related disease but, recently, it has been reported to be prevalent also in younger patients with autoimmune diseases. Specifically, the association of sarcopenia and autoimmune diseases such as rheumatoid arthritis has been studied in detail. Although the pathogenesis of sarcopenia in autoimmune diseases has not been elucidated, chronic inflammation is believed to contribute to sarcopenia, and moreover the pathogenesis seems to be different depending on the respective underlying disease. The definition of sarcopenia differs among studies, which limits direct comparisons. Therefore, in this review, we cover various definitions of sarcopenia used in previous studies and highlight the prevalence of sarcopenia in diverse autoimmune diseases including rheumatoid arthritis, spondyloarthritis, systemic sclerosis, inflammatory bowel disease, and autoimmune diabetes. In addition, we cover the pathogenesis and treatment of sarcopenia in autoimmune and rheumatic diseases. This review provides a comprehensive understanding of sarcopenia in various autoimmune diseases and highlights the need for a consistent definition of sarcopenia.
\end{abstract}

Keywords: sarcopenia; rheumatic disease; autoimmune disease; rheumatoid arthritis; inflammatory bowel disease; type 1 diabetes 


\section{Introduction}

The loss of muscle mass and function with aging is a natural phenomenon. In the seventh and eighth decade of life, muscle strength decreases by $20-40 \%$ and the degree of reduction increases gradually [1]. The decrease in skeletal muscle mass, strength, and function associated with aging is termed sarcopenia [2-4]. Sarcopenia is associated with daily life disability, falls in older people, and a high risk of all-cause mortality $[5,6]$. Furthermore, there is a financial burden associated with sarcopenia because the hospitalization costs for patients with sarcopenia are significantly higher than those without sarcopenia [7]. As the clinical importance of sarcopenia has become apparent, it is now considered to be a disease entity in the International Classification of Diseases (ICD) [8]. Although sarcopenia is usually considered to be an age-related disorder, younger people with various clinical conditions also suffer from sarcopenia. Age-related sarcopenia with no other causes is called "primary sarcopenia", whereas when one or more other causes such as malnutrition are evident, sarcopenia is classified as "secondary sarcopenia" [4]. In many cases, sarcopenia is age-related and is also a multifactorial problem [9]. It is well known that endocrine diseases or malignancies promote sarcopenia [10]. Likewise, chronic inflammation is also a paramount risk factor for sarcopenia [10,11]. From this point of view, autoimmune diseases with persistent chronic inflammation due to autoreactive immune response, could be a risk factor for sarcopenia. Indeed, a recent study showed that having any autoimmune disease was associated with sarcopenia with an odds ratio (OR) of 1.83 [12]. In addition, the association between rheumatoid arthritis (RA) and sarcopenia is well established. Nevertheless, to date, there are no comprehensive reviews regarding the relationship of sarcopenia and autoimmune diseases. This review addresses this gap and covers the association between sarcopenia and autoimmune or rheumatic diseases. This review mainly addresses RA rather than other diseases due to a difference in the sufficiency of studies.

\section{Definition and Diagnosis of Sarcopenia}

In 1989, Irwin Rosenberg first coined the term "sarcopenia" (Greek "sarx" or flesh and "penia" or loss) to define the decrease of skeletal muscle mass, however, until now there has been no unified definition or diagnosis of sarcopenia [2,3]. Baumgartner et al. defined sarcopenia based on skeletal muscle mass [13]. The skeletal muscle mass index (SMI) was defined as appendicular skeletal muscle mass (ASM)/height ${ }^{2}\left(\mathrm{~kg} / \mathrm{m}^{2}\right)$, and sarcopenia was defined if the SMI was two standard deviations below the mean of a gender-specific reference group [13]. After a few years, Janssen et al. proposed cut points of height-adjusted skeletal muscle mass that were associated with a physical disability risk [14]. Later, several consensus groups proposed a definition using both muscle mass and function [4,15-18]. In 2010, the European Working Group on Sarcopenia in Older People (EWGSOP) defined sarcopenia as "a syndrome characterized by progressive and generalized loss of skeletal muscle mass and strength with a risk of adverse outcomes such as physical disability, poor quality of life and death", a definition that now represents the most widely used definition in the clinical realm [4]. According to the EWGSOP, the definition of sarcopenia was (1) having low muscle mass and (2) having low muscle strength or low physical performance [4]. The Foundation of the National Institute of Health (FNIH) [15], the International Working Group on Sarcopenia (IWGS) [16], and the European Society on Clinician Nutrition and Metabolism special interest groups (ESPEN SIG) [17] also proposed a definition for sarcopenia that contained both muscle mass and function. The Asian Working Group for Sarcopenia (AWGS) took a similar approach for sarcopenia but proposed a new and more appropriate cut-off value for Asians, considering that already proposed cut-points had been calculated from Caucasian data [18]. Recently, the European Working Group on Sarcopenia in Older People 2 (EWGSOP2) revised the definition of sarcopenia and characterized it by (1) low muscle strength and (2) low muscle quantity or quality [19]. This change reflected the study results that muscle strength is a more important prognostic factor than muscle mass [20-23]. 


\section{Epidemiology of Sarcopenia in Autoimmune and Rheumatic Disease Patients}

Table 1 shows the prevalence of sarcopenia in autoimmune and rheumatic diseases. The prevalence of sarcopenia varies based on the type of autoimmune disease, and also the different definitions used, as well as the subject groups analyzed. Overall, the clinical definitions are heterogeneous. On the one hand, many studies have defined sarcopenia using only one aspect, muscle mass or lean mass which are calculated using the SMI or the free fat mass index (FFMI), respectively. On the other hand, other studies have defined it using muscle mass plus muscle strength (e.g., handgrip strength) and performance (e.g., TUG, timed up and go). Furthermore, the cut-off value for sarcopenia differs among studies. The column "definition of sarcopenia" highlights the respective criteria used to define sarcopenia. Krajewska-Włodarczyk et al. demonstrated that the difference in definition affected study results [24]. In female patients with psoriatic arthritis (PsA), the prevalence of sarcopenia was 13.7, 49.0, and 43.1\%, respectively, when it was diagnosed using the following different definitions of SMI: (1) appendicular muscle mass/height ${ }^{2}<5.45 \mathrm{~kg} / \mathrm{m}^{2}$ [13], (2) skeletal muscle mass/weight $\times 100<27.6 \%$ [25], (3) skeletal muscle mass/weight $\times 100<27.6 \%$ with TUG $>14 \mathrm{~s}$ [25]. The heterogeneity of prevalence due to the different definitions of sarcopenia makes the need for a unified definition and diagnostic criteria for sarcopenia urgent. 
Table 1. Prevalence of Sarcopenia in Patients with Autoimmune and Rheumatic Diseases.

\begin{tabular}{|c|c|c|c|c|c|c|}
\hline Author & Prevalence $(\%)$ & & Patients (N) & Group Feature & $p$-Value & $\begin{array}{l}\text { Definition of Sarcopenia } \\
\text { (Cut-off) }\end{array}$ \\
\hline \multicolumn{7}{|c|}{ Rheumatoid Arthritis } \\
\hline \multirow{3}{*}{ Dao et al. [26] ${ }^{1}$} & Purely sarcopenic & 18.1 & \multirow{3}{*}{105} & \multirow{3}{*}{ Vietnamese, female } & 0.007 & \multirow{3}{*}{ FFMI (Hull et al. [27]) } \\
\hline & Sarcopenic obesity $^{2}$ & 12.4 & & & 0.002 & \\
\hline & Total & 30.5 & & & - & \\
\hline \multirow{3}{*}{ Santos et al. [28] ${ }^{1}$} & Purely sarcopenic & 4.5 & \multirow{3}{*}{89} & \multirow{3}{*}{ Caucasian, Portuguese, female } & $>0.05^{3}$ & \multirow{3}{*}{$\begin{array}{l}\text { FFMI z score } \leq-2 \\
\text { (Schutz et al. [29]) }\end{array}$} \\
\hline & Sarcopenic obesity $^{2}$ & 5.6 & & & 0.01 & \\
\hline & Total & 10.1 & & & - & \\
\hline \multirow{3}{*}{ Giles et al. [30] } & Male & 33.3 & 72 & \multirow{3}{*}{ American } & $0.157^{3}$ & \multirow{3}{*}{ SMI (Janssen et al. [14]) } \\
\hline & Female & 21.4 & 117 & & 0.004 & \\
\hline & Total & 25.9 & 189 & & - & \\
\hline Doğan et al. [31] & 43.3 & & 30 & $\begin{array}{c}\text { Female, } \\
\text { Age 35-50 }\end{array}$ & 0.004 & SMI (Janssen et al. [14]) \\
\hline Tournadre et al. [32] & 28.6 & & 21 & $\begin{array}{c}\text { Active RA } \\
(\mathrm{DAS} 28>3.2)\end{array}$ & $<0.05$ & SMI (Baumgartner et al. [13]) \\
\hline Lin et al. [33] & 45.1 & & 457 & Chinese & $<0.05^{4}$ & SMI (AWGS [18]) \\
\hline Ngeuleu et al. [34] & 39.8 & & 123 & Moroccan & - & SMI (Baumgartner et al. [13] \\
\hline Tada et al. [35] & 28.0 & & 100 & Japanese & - & AWGS [18] \\
\hline Mochizuki et al. [36] & 29.6 & & 240 & $\begin{array}{l}\text { Japanese, } \\
\text { age } \geq 65\end{array}$ & - & AWGS [18] \\
\hline Torii et al. [37] & 37.1 & & 388 & Japanese, female & - & EWGSOP [4], AWGS [18] \\
\hline Vlietstra et al. [38] & 17.1 & & 82 & New Zealander & - & SMI (FNIH [15]) \\
\hline Barone et al. [39] & 21.0 & & 76 & Caucasian, Italian, age 40-75 & - & $\begin{array}{l}\text { SMI (Janssen et al. [14]), } \\
\text { HS (Lauretani et al. [40]) }\end{array}$ \\
\hline
\end{tabular}

Ankylosing Spondylitis 
Table 1. Cont.

\begin{tabular}{|c|c|c|c|c|c|c|}
\hline Author & Prevalence $(\%)$ & & Patients (N) & Group Feature & $p$-Value & $\begin{array}{l}\text { Definition of Sarcopenia } \\
\text { (Cut-off) }\end{array}$ \\
\hline Barone et al. [39] & 22.7 & & 22 & Caucasian, Italian, age 40-75 & - & $\begin{array}{l}\text { SMI (Janssen et al. [14]), } \\
\text { HS (Lauretani et al. [40]) }\end{array}$ \\
\hline El Maghraoui et al. [41] & 34.3 & & 67 & Moroccan, male & - & EWGSOP [4] \\
\hline \multicolumn{7}{|c|}{ Psoriatic Arthritis } \\
\hline Barone et al. [39] & 20.0 & & 70 & Caucasian, Italian, age 40-75 & - & $\begin{array}{l}\text { SMI (Janssen et al. [14]), } \\
\text { HS (Lauretani et al. [40]) }\end{array}$ \\
\hline \multirow{3}{*}{$\begin{array}{c}\text { Krajewska-Włodarczyk et } \\
\text { al. [24] }\end{array}$} & 13.7 & & \multirow{3}{*}{51} & \multirow{3}{*}{ Polish, age $50-75$, female } & \multirow{3}{*}{-} & SMI (Baumgartner et al. [13]) \\
\hline & 49.0 & & & & & SMI (Janssen et al. [25]) \\
\hline & 43.1 & & & & & $\begin{array}{c}\text { SMI(Janssen et al. [25]), } \\
\text { TUG }>14 \mathrm{~s}\end{array}$ \\
\hline \multicolumn{7}{|c|}{ Systemic Lupus Erythematosus } \\
\hline \multirow{3}{*}{ Santos et al. [28] ${ }^{1}$} & Purely sarcopenic & 10.9 & \multirow{3}{*}{92} & \multirow{3}{*}{ Caucasian, Portuguese, female } & 0.01 & \multirow{3}{*}{ FFMI (Schutz et al. [29]) } \\
\hline & Sarcopenic obesity $^{2}$ & 6.5 & & & 0.009 & \\
\hline & Total & 17.4 & & & - & \\
\hline \multicolumn{7}{|c|}{ Systemic Sclerosis } \\
\hline Caimmi et al. [42] & 20.7 & & 140 & Italian & - & SMI (Baumgartner et al. [13]) \\
\hline Siegert et al. [43] & 22.5 & & 129 & German, $91.5 \%$ female & - & EWGSOP [4] \\
\hline \multirow[b]{2}{*}{ Corallo et al. [44] } & 41.9 & & \multirow[b]{2}{*}{62} & \multirow[b]{2}{*}{ Caucasian, Italian } & \multirow[b]{2}{*}{-} & SMI (Baumgartner et al. [13]) \\
\hline & 54.8 & & & & & $\begin{array}{c}\text { HS } \\
(\text { Male }<30, \text { Female }<20)\end{array}$ \\
\hline \multicolumn{7}{|c|}{$\begin{array}{c}\text { Inflammatory Bowel Disease } \\
\text { Ulcerative colitis }\end{array}$} \\
\hline Zhang et al. [45] & 27.3 & & 99 & Chinese. & $<0.05$ & SMI (Fearon et al. [46]) \\
\hline Cushing et al. [47] & 69.5 & & 82 & Admitted for ASUC & - & SMI (Fearon et al. [46]) \\
\hline Mager et al. [48] & 14.8 & & 27 & Age 5-18 & - & SMM z score $<-2[49]$ \\
\hline
\end{tabular}


Table 1. Cont

\begin{tabular}{|c|c|c|c|c|c|}
\hline Author & Prevalence (\%) & Patients (N) & Group Feature & $p$-Value & $\begin{array}{c}\text { Definition of Sarcopenia } \\
\text { (Cut-off) }\end{array}$ \\
\hline Bamba et al. [50] & 48.3 & 29 & Japanese & - & SMI (Nishikawa et al. [51]) \\
\hline Adams et al. [52] & 50.0 & 14 & American & - & SMI (Prado et al. [53]) \\
\hline \multicolumn{6}{|c|}{ Crohn's Disease } \\
\hline Zhang et al. [45] & 59.0 & 105 & Chinese & $<0.05$ & SMI (Fearon et al. [46]) \\
\hline Mager et al. [48] & 31.0 & 58 & Age 5-18 & - & SMM z score $<-2$ [49] \\
\hline Zhang et al. [54] & 61.4 & 114 & Chinese, required BR & - & SMI (Fearon et al. [46]) \\
\hline O'Brien et al. [55] & 39.0 & 77 & Retrospectively selected (BR) & - & SMI (Martin et al. [56]) \\
\hline Bamba et al. [50] & 37.2 & 43 & Japanese & - & SMI (Nishikawa et al. [51]) \\
\hline Thiberge et al. [57] & 33.6 & 149 & French & - & SMI (Mourtzakis et al. [58]) \\
\hline Adams et al. [52] & 44.7 & 76 & American & - & SMI (Prado et al. [53]) \\
\hline Lee et al. [59] & 50.6 & 79 & Korean & - & SMI (Kim et al. [60]) \\
\hline Cravo et al. [61] & 31.0 & 71 & Portuguese & - & SMI (Martin et al. [56]) \\
\hline Carvalho et al. [62] & 41.4 & 58 & Portuguese & - & SMI (Prado et al. [53]) \\
\hline \multicolumn{6}{|c|}{$\begin{array}{c}\text { Diabetes } \\
\text { Type } 1 \text { Diabetes Mellitus }\end{array}$} \\
\hline Mori et al. [63] & 16.6 & 36 & Japanese & - & AWGS [18] \\
\hline \multicolumn{6}{|c|}{ Latent Autoimmune Diabetes in Adults } \\
\hline Bouchi et al. [64] & 35.0 & 20 & Japanese & 0.022 & AWGS [18] \\
\hline
\end{tabular}

Autoimmune Liver Disease

(Autoimmune Hepatitis, Primary Biliary Cirrhosis, Primary Sclerosing Cholangitis)

Montano-Loza et al. [65] $41.8 \quad 55 \quad$ Canadian, evaluated for LT $\quad$ -

FFMI, free fat mass index; SMI, skeletal muscle mass index; RA, rheumatoid arthritis; DAS28, disease activity score in 28 joints; HS, handgrip strength; TUG, timed up and go; ASUC, acute severe ulcerative colitis; SMM, skeletal muscle mass; BR, bowel resection; LT, liver transplantation. ${ }^{1}$ Sarcopenia was divided into two groups, purely sarcopenic and sarcopenic obesity; ${ }^{2}$ Sarcopenic obesity refers to a medical condition in which the loss of muscle is accompanied by increased fat mass; ${ }^{3}$ Not statistically significant; ${ }^{4} p$-value was measured respectively according to sex and age. Each $p$-value was $<0.05$. 


\subsection{Rheumatoid Arthritis}

Among the studies investigating the prevalence of sarcopenia in autoimmune diseases, most studies have been performed in RA patients. Dao et al. [26], Santos et al. [28], Giles et al. [30], Doğan et al. [31], Tournadre et al. [32], and Lin et al. [33] performed cross-sectional studies, and revealed that the overall prevalence of sarcopenia was significantly higher in RA patients as compared with controls. In twelve RA studies, as highlighted in Table 1, the prevalence of sarcopenia ranged from 10.1 to $45.1 \%$ and the median value was $29.1 \%$ [26,28,30-39]. There are significant gaps among the figures. The gaps seem to result from the diversity in the definition of sarcopenia and the different features of each group such as drug use, disease activity, and ethnicity. In conclusion, RA patients are susceptible to sarcopenia, but it is difficult to determine the exact prevalence of sarcopenia in RA from the studies due to their heterogeneity.

\subsection{Spondyloarthritis}

We found three valid studies concerning the prevalence of sarcopenia in spondyloarthritis (SpA). Barone et al. studied Caucasian SpA patients aged between 40 and 75 years, excluding those with obesity; 22 patients with ankylosing spondylitis (AS) and 70 patients with PsA [39]. The prevalence of sarcopenia diagnosed using the SMI and handgrip strength was $22.7 \%$ in AS, and $20.0 \%$ in PsA [39]. The difference in the prevalence of sarcopenia between RA, PsA, and AS was not significant, whereas the prevalence of pre-sarcopenia (decreased muscle mass without reduced strength) was significantly different (As > PsA > RA) in the study [39]. In male Moroccan AS patients, the prevalence of sarcopenia was $34.3 \%$ according to the definition of the EWGSOP [41]. In another study of female patients with PsA from Poland with an age range of 50 to 75 years, the prevalence of sarcopenia was 13.7, 49.0, and $43.1 \%$, each for different definitions [24].

\subsection{Systemic Lupus Erythematosus}

In the study by Santos et al., 16 out of 92 participants (17.4\%) with a diagnosis of systemic lupus erythematosus (SLE) were sarcopenic [28]. Among them, 10.9\% of patients were sarcopenic but not obese, and $6.5 \%$ patients were both sarcopenic and obese. Both numbers were significantly higher than the controls (purely sarcopenic $p=0.01$ and sarcopenic obesity $p=0.009$ ).

\subsection{Systemic Sclerosis}

Three studies calculated the prevalence of sarcopenia in systemic sclerosis (SSc). The prevalence was $20.7 \%$ when defining sarcopenia using the SMI [42] and $22.5 \%$ in a study from Germany, which included $91.5 \%$ females and followed the definition of EWGSOP [4,43]. Another study reported higher prevalence rates of 41.9 and $54.8 \%$ applying the SMI and handgrip strength criteria, respectively [44].

\subsection{Inflammatory Bowel Disease}

To estimate the degree of sarcopenia in inflammatory bowel disease (IBD), a few studies used the lumbar SMI assessed by computed tomography (CT) scan, dual-energy X-ray absorptiometry (DXA), or bioelectrical impedance analysis (BIA). Zhang et al. observed that sarcopenia was more prevalent in ulcerative colitis (UC) and Crohn's disease (CD) as compared with controls (all $p<0.05$ ) [45]. Among patients with IBD, the prevalence of sarcopenia was significantly higher in CD patients $(p<0.05)$ [45]. The prevalence of sarcopenia in UC ranged from 14.8 to $69.5 \%[45,47,48,50,52]$. The studies used the lumbar SMI to define sarcopenia with different cut-off points. The reason for this large gap seems to result from the difference of respective inclusion criteria of the subjects. The highest prevalence of $69.5 \%$ was measured in patients who were hospitalized due to acute severe UC [47], and the lowest was in newly diagnosed patients with an age under 13 years [48]. In CD, the prevalence of sarcopenia was higher than in other autoimmune diseases. It ranged between 31.0 and $61.4 \%$ and 
the median was $40.2 \%[45,48,50,52,54,55,57,59,61,62]$. There are two reasons why the numbers could have been overestimated. First, the subject groups were also skewed as described above for UC. In fact, in general, the CT data, which was used to diagnose sarcopenia, was scarce in stable patients. Therefore, subjects undergoing surgery after the CT scan were included to propose the frequency of sarcopenia [54,55], or hospitalized due to disease exacerbation [50], or suspected complications of $\mathrm{CD}$ [57]. Second, there could be an overlap between the two studies showing the highest prevalence because the data were measured in an identical hospital in a similar time period [45,54].

\subsection{Other Autoimmune Diseases}

The prevalence of sarcopenia in type 1 diabetes mellitus (T1DM) and latent autoimmune diabetes in adults (LADA) was 16.6 and $35.0 \%$, respectively $[63,64]$. The subjects were Japanese, and sarcopenia was diagnosed according to the AWGS. In LADA, the prevalence was significantly higher than in controls [64]. Among Canadian autoimmune liver disease patients who were evaluated for liver transplantation, $41.8 \%$ of the patients were sarcopenic as diagnosed using the SMI [65].

\section{Rheumatoid Arthritis and Sarcopenia}

RA is a chronic inflammatory autoimmune disease that affects multiple synovial joints. Sarcopenia is a frequent comorbidity of RA that occurs in $10.1-45.1 \%$ of patients (Table 1 ). Occasionally, loss of muscle is accompanied by increased fat mass which is called sarcopenic obesity. Rheumatoid cachexia is a more serious condition and refers to the state of exhaustion and loss of overall body composition, including muscle and fat [66]. It is also a common condition in RA with a prevalence of $15-32 \%$ according to a meta-analysis [67]. Many studies have supported the idea that RA patients have lower skeletal muscle mass resulting in a higher prevalence of sarcopenia as compared with those without RA $[26,31,68,69]$. As shown in Table 2, sarcopenia in RA is clinically meaningful, since it is associated with the incidence of low bone mineral density, falls, and fractures [36,37]. In addition, sarcopenic RA patients have endothelial dysfunction and a higher cardiometabolic risk $[34,70]$. The Health Assessment Questionnaire Disability Index (HAQ-DI) is a measure to assess the functional ability of chronically ill patients, especially RA [71]. Several studies have reported that high HAQ-DI scores are associated with sarcopenia in RA [30,33,72,73]. Study findings regarding sarcopenia and RA are available in Table S1.

Table 2. Study Findings Related to Sarcopenia in Patients with Rheumatoid Arthritis.

\begin{tabular}{|c|}
\hline Associated Factors \\
\hline Age $[36,37]$ \\
\hline BMI [34-36] \\
\hline Body fat mass $[35,38]$ \\
\hline Disease duration $[37,74]$ \\
\hline Bone erosion and mineral density $[34,36]$ \\
\hline Malnutrition and protein intake $[37,72]$ \\
\hline Joint damage $[30,33,37]$ \\
\hline Functional status (HAQ score) $[26,30,33,72,73]$ \\
\hline CRP level $[30,36,68,72]$ \\
\hline ESR $[68,72]$ \\
\hline $\operatorname{RF}[26,30]$ \\
\hline МMP3 [35] \\
\hline Use of GC $[38,72,75,76]$ \\
\hline Treatment \\
\hline IL-6 inhibitor (TCZ) [32] \\
\hline DMARDs $[30,37]$ \\
\hline$\beta_{2}$-adrenoceptor agonist (formoterol) [77] \\
\hline Antioxidant [78] \\
\hline Neuromuscular electrical stimulation [79] \\
\hline
\end{tabular}


Table 2. Cont.

\begin{tabular}{c}
\hline Associated Factors \\
\hline Risk \\
Falls [37] \\
Fractures [37] \\
Low bone mineral density [37] \\
Cardiometabolic risk [34] \\
Endothelial dysfunction [70] \\
\hline Cytokines/Pathways \\
\hline IL-1 $\beta$ [66,80] \\
IL-6 [81] \\
TNF- $\alpha$ [66,81] \\
NF-Kb [80] \\
p38 MAPK [80] \\
pSTAT3 [80] \\
Pax7 [80] \\
Myostatin [80] \\
MyoD [80,82] \\
Myogenin [80,82] \\
IGFBP-5 [82] \\
IGFBP-3 [82] \\
atrogin-1 [80,82] \\
MuRF-1 [80,82]
\end{tabular}

BMI, body mass index; $\mathrm{HAQ}$, health assessment questionnaire; CRP, C-reactive protein; $\mathrm{ESR}$, erythrocyte sedimentation rate; RF, rheumatoid factor; MMP3, matrix metallopeptidase 3; GC, glucocorticoid; IL-6, interleukin-6; TCZ, tocilizumab; DMARDs, disease-modifying antirheumatic drugs; IL- $1 \beta$, interleukin- $1 \beta$; TNF- $\alpha$, tumor necrosis factor- $\alpha$; NF- $\mathrm{kB}$, nuclear factor kappa-light-chain-enhancer of activated B cells; MAPK, mitogen-activated protein kinase; pSTAT3, phospho-signal transducer and activator of transcription 3; Pax7, paired box 7; IGFBP, insulin-like growth factor binding protein; MuRF-1, muscle RING-finger 1.

\subsection{Associated Factors}

The factors associated with sarcopenia in RA have been demonstrated in many studies (Table 2). Old age [36,37], BMI [34-36], high body fat mass [35,38], longer disease duration [37,74], bone erosion [34], low hip bone mineral density [36], malnutrition [37], low protein intake [72], and joint damage $[30,33,37]$ were all associated with sarcopenia. Acute phase reactants such as C-reactive protein (CRP) and erythrocyte sedimentation rate (ESR) [30,36,68,72], rheumatoid factor (RF) [26,30], and matrix metalloprotease 3 (MMP3) [35] were also associated. However, conflicting results have been found for other factors. Disease activity, which was measured by the disease activity score in 28 joints (DAS28), was associated with abnormal body composition in one study [26], while others did not find a significant association $[30,34,35,38]$. Tada et al. stated that no significant correlation between sarcopenia and RA activity in their study could be due to the relatively mild disease activity of the subjects [35].

\subsection{Pathogenesis}

Interleukin-1 $\beta$ (IL-1 $\beta$ ), interleukin-6 (IL-6), and tumor necrosis factor- $\alpha$ (TNF- $\alpha$ ) are proinflammatory cytokines which are thought to be pathogenic in RA. These cytokines are also associated with sarcopenia and resting energy expenditure in RA patients, as shown in Figure 1 [66,80,81]. These relationships suggest that the inflammatory response of RA promotes sarcopenia. It has been demonstrated from an animal study that muscle wasting in RA was due to the disease itself and not associated with decreased mobility [83]. The exact mechanism of muscle wasting in RA has not yet been elucidated in detail, but muscle wasting can be due to proteolysis by activated catabolic responses and not due to decreased myogenic responses [82]. In adjuvant-induced arthritis (AIA) rats, which is a model of arthritis-induced muscle wasting, increased gene expression of IL-1 $\beta$ 
accompanied with upregulation of E3 ubiquitin ligases (atrogin-1 and muscle RING-finger 1 (MuRF-1)), phosphorylated p38 mitogen-activated protein kinase (MAPK)/p38 MAPK, and active nuclear factor kappa-light-chain-enhancer of activated B cells (NF- $\mathrm{kB}$ ) have been reported [80]. It is known that NF- $\mathrm{KB}$ and p38 MAPK activate the ubiquitin proteasome system [84]. These signaling pathways are related to muscle wasting in RA and they may be activated by IL-1 $\beta$ [80]. In contrast, myogenic regulatory factors such as $\mathrm{MyoD}$, paired box 7 (Pax7), and myogenin are also increased in animals with muscle wasting [80]. These results suggest that muscle repair or anabolic compensation occur simultaneously with muscle wasting.

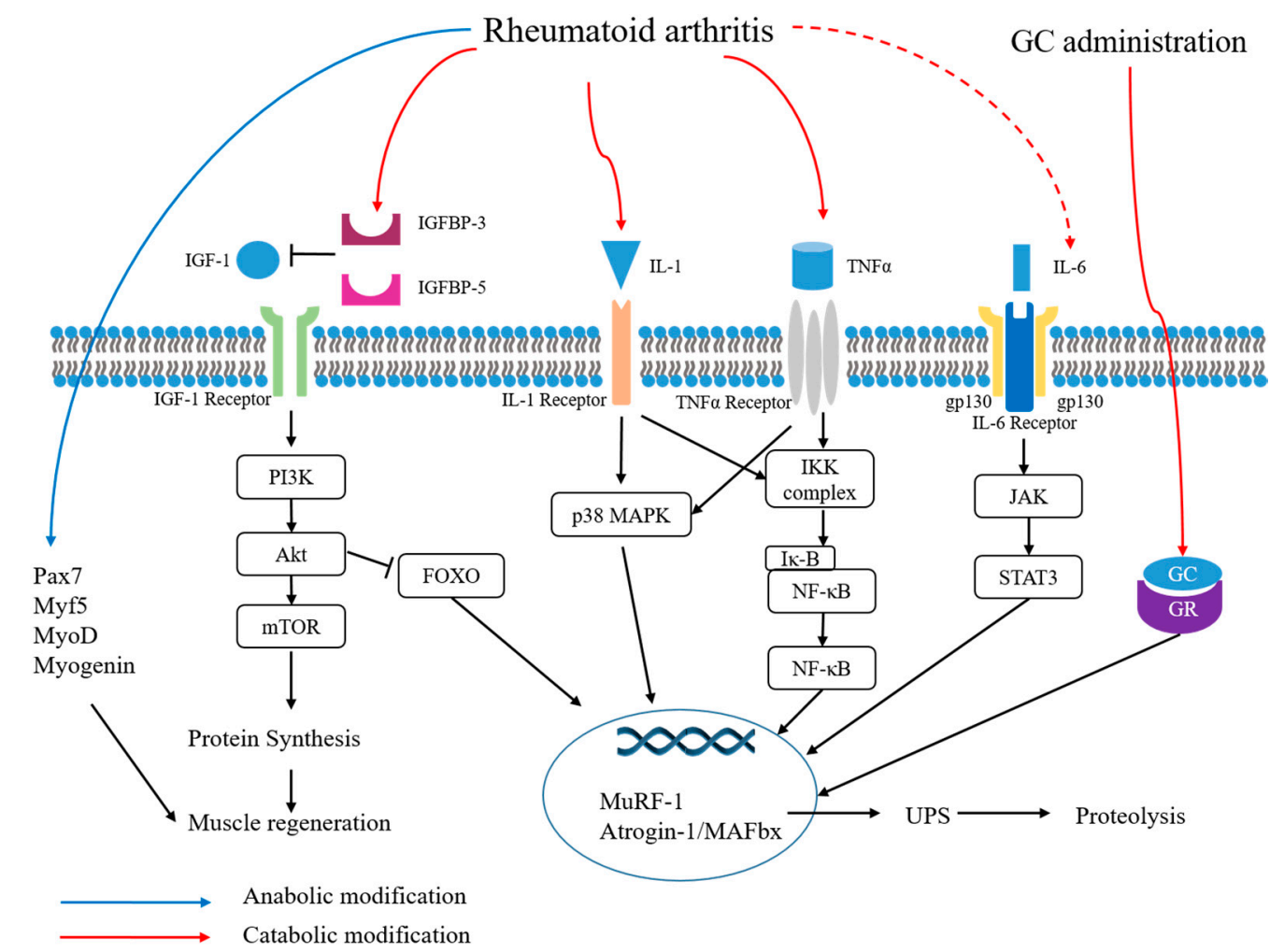

Figure 1. Mechanisms of sarcopenia and metabolic modifications in rheumatoid arthritis. IGF-1, insulin-like growth factor-1; IGFBP, insulin-like growth factor binding protein; IL-1, interleukin-1; TNF- $\alpha$, tumor necrosis factor- $\alpha$; GC, glucocorticoid; GR, glucocorticoid receptor; gp 130, glycoprotein 130; Pax7, paired box 7; PI3K, phosphoinositide 3-kinase; mTOR, mammalian target of rapamycin; MAPK, mitogen-activated protein kinase; IKK, IкB kinase; IкB, inhibitor of nuclear factor kappa B; NF- $к \mathrm{~B}$, nuclear factor kappa-light-chain-enhancer of activated B cells; JAK, Janus kinase; STAT3, signal transducer and activator of transcription 3; MuRF-1, muscle RING-finger 1; UPS, ubiquitin proteasome system.

\subsection{Treatments}

Although available drugs for sarcopenia do not exist, it seems that treatment for RA is also helpful for RA associated sarcopenia (Table 2). Although there have been conflicting results that have indicated the use of disease-modifying antirheumatic drugs (DMARDs) was not related to changes in body composition [30], a recent study has revealed that the use of biologic DMARD was negatively associated with sarcopenia in RA [37]. A therapeutic possibility of a biologic DMARD, tocilizumab (anti-IL6 receptor antibody), has also been proposed in other studies. From a prospective study in RA patients, a year of treatment with tocilizumab increased lean mass and the SMI [32]. In addition, AIA rat studies have suggested the possibility that $\beta 2$-adrenoceptor agonist (formoterol) [77], antioxidants [78], and neuromuscular electrical stimulation [79] could prevent skeletal muscle dysfunction or muscle loss in RA. In contrast, treatment of RA using glucocorticoids (GCs) seemed to exacerbate sarcopenia. 
It has been reported that GCs use was positively associated with low lean mass or sarcopenia in RA patients [38,72]. In a chronic polyarthritis mouse model, GCs treatment prevented inflammatory bone loss but significantly increased muscle wasting [75]. A recent study by Yamada et al. revealed that after administration of GCs for a year, 13.4\% of the patients developed sarcopenia [76] and also, an average GCs use of $\geq 3.25 \mathrm{mg} /$ day over a year was significantly associated with sarcopenia with a OR of 8.81 (95\% CI 1.146-7.9, $p=0.037$ ) [76]. The results imply that GC treatment in RA patients should be used cautiously and that reduction or stopping of GCs administration could alleviate treatment-related sarcopenia. However, the duration of steroid use was not associated with sarcopenia [34].

\section{Other Rheumatic Diseases and Sarcopenia}

\subsection{Spondyloarthritis}

$\mathrm{SpA}$ is a group of rheumatic diseases characterized by inflammation in the axial skeleton and peripheral joints, and by specific clinical symptoms such as uveitis and psoriasis [85]. SpA includes AS, PsA, and other diseases, but previous studies only investigated sarcopenia in AS and PsA. As in other rheumatic diseases, patients with SpA have been shown to be susceptible to sarcopenia [86], and it has been associated with two major factors (Table 3, Table S2). First, sarcopenia was associated with disease activity which was assessed using the Bath Ankylosing Spondylitis Disease Activity Index (BASDAI). Aguiar et al. highlighted that the SMI and the BASDAI have a significant negative correlation in male AS and PsA patients [86]. In addition, the Bath Ankylosing Spondylitis Functional Index (BASFI) was also correlated with sarcopenia in males [86]. Another study confirmed that in AS patients, sarcopenia was associated with BASDAI [41]. Second, sarcopenia was associated with bone mineral abnormality. Sarcopenic PsA patients had a significantly higher prevalence of osteoporosis than non-sarcopenic PsA patients [24]. Another study showed that sarcopenia was associated with lower bone mineral density in AS patients which supported this assumption [41]. However, other factors such as disease duration were not associated with sarcopenia.

\subsection{Systemic Sclerosis}

SSc is an autoimmune rheumatic disease characterized by vasculopathy, tissue fibrosis, and internal organ involvement [87]. SSc patients tend to have decreased muscle strength and endurance related to physical functional disability [88] and $20.7-54.8 \%$ of patients exhibit sarcopenia [42-44]. Sarcopenia in SSc has been associated with multiple organ involvements of the disease including lung, skin, esophagus, microvasculature, and urinary tracts (Table 3, Table S2) [42,44,87]. Among the specific characteristics of SSc, a longer duration of disease was also associated with sarcopenia $[42,44,89]$. In addition, low physical function [43], malnutrition [44], and high ESR [44] were also associated with sarcopenia similar to the findings in RA (Table 3). In particular, elevated ESR in SSc reflected disease severity well [90]. Considering all these results, sarcopenia seems to be related to the progression and severity of SSc and muscle weakness and atrophy could result directly from muscle involvement of SSc [91]. Thus, there could be a considerable overlap in domains of sarcopenia and muscle involvement in SSc. Interestingly, sarcopenic patients receive more immunosuppressive drugs than non-sarcopenic patients [43]. It is counterintuitive that alleviating disease activity with immunosuppressive drugs is more related to sarcopenia. Siegert et al. interpreted that receiving more drugs indicated a more severe state and a longer duration of disease [43]. Another study indicated that polypharmacy itself could directly contribute to sarcopenia [92]. However, the association between the use of multiple immunosuppressive drugs and sarcopenia needs further study. Interventional studies are still scarce but there is a single study highlighting that medical nutrition therapy reversed sarcopenia in patients with GI tract involvement of SSc [93]. 
Table 3. Associated Factors Related to Sarcopenia in Patients with Rheumatic Diseases Other Than Rheumatoid Arthritis.

\begin{tabular}{c}
\hline Spondyloarthritis \\
\hline BASDAI (in AS and male SpA) [41,86] \\
BASFI (in male SpA) [86] \\
Bone mineral density (in AS) [41] \\
Osteoporosis (in PsA) [24] \\
Systemic Sclerosis \\
\hline Lung involvement (Medsger severity score) [42] \\
Skin involvement (mRSS, Medsger severity score) [42,44] \\
Microvascular involvement (capillaroscopy score) [44] \\
Esophageal involvement [44] \\
Overactive bladder [87] \\
Disease duration [42,44,89] \\
DLCO [42,44] \\
Malnutrition [44] \\
ESR [44]
\end{tabular}

BASDAI, Bath Ankylosing Spondylitis Disease Activity Index; BASFI, Bath Ankylosing Spondylitis Function Index; mRSS, modified Rodnan skin score; DLCO, diffusing capacity for carbon monoxide; ESR, erythrocyte sedimentation rate

\section{Inflammatory Bowel Disease and Sarcopenia}

IBD includes CD and UC which are characterized by chronic relapsing bowel inflammation. The etiology of IBD remains unclear but environmental and genetic factors seem to be involved in autoimmune pathogenicity [94,95]. In IBD patients, sarcopenia is frequent and the muscle mass reduces over time accompanied by an increased BMI $[96,97]$. According to a follow-up study, the prevalence of sarcopenia increased from 9.3 to $16.3 \%$ until a year after the diagnosis, although sarcopenia did not increase after that time [97]. Sarcopenia in IBD has been studied for its prognostic implication and associated factors (Table S3). It has been considered to be a predictive factor for medical rescue therapy and bowel resection $[47,50,52]$, and postoperative complications $[54,62,98,99]$ in both CD and UC. Additionally, in CD, sarcopenia is associated with primary non-response to anti-TNF treatment, and therefore sarcopenic IBD patients need adjusted dosing [100]. The mechanism of sarcopenia in IBD patients is believed to be associated with disease-related inflammation and nutritional problems. Muscle radiation attenuation, which is an inverse parameter of muscle fat content [101], has been associated with severe phenotypes of disease such as a history of a stricturing, penetrating complication, or previous resection surgery for CD [61]. In addition, sarcopenia has been associated with high disease activity assessed by the Mayo score in UC [45]. Inflammatory markers such as CRP and ESR, have been associated with sarcopenia in IBD $[59,99]$. In addition, vitamin D in pediatric patients, as well as hemoglobin and albumin in adult patients have been associated with sarcopenia [48,59]. Decreased motility also seems to contribute to sarcopenia in pediatric patients [102]. Additionally, we suggest a possibility that the gut microbiome could be related to sarcopenia in IBD. In IBD, the composition and function of microbiome are altered. It has been reported that IBD patients have increased proinflammatory bacterial species (Escherichia, Fusobacterium) and decreased anti-inflammatory bacterial species (Faecalibacterium) with decreased amino acid biosynthesis of the microbiome [103]. In addition, it has been suggested that the gut microbiome could directly affect the muscle by modulating amino acid bioavailability and the production of proinflammatory cytokines [104]. In an acute leukemia mouse model, oral supplementation of lactobacillus species decreased atrogin-1, MuRF1, and inflammatory cytokines [105]. A direct association of muscle and gut microbiome in sarcopenic IBD should be investigated by animal and clinical studies. To alleviate sarcopenia in IBD, treatment of the disease through reduction in inflammation would be effective. Infliximab, a TNF- $\alpha$ antibody, increased both muscle volume and strength in CD patients [106], and moreover, colectomy 
increased SMI and serum albumin with a decrease in the prevalence of sarcopenia in UC patients [45]. Nutritional management could also be needed for better postoperative prognosis in sarcopenic IBD patients, although it is not effective directly in the management of sarcopenia [54].

\section{Autoimmune Diabetes and Sarcopenia}

T1DM is a chronic autoimmune disease characterized by hyperglycemia due to pancreatic islet $\beta$-cell destruction [107]. T1DM patients have a high prevalence of sarcopenia and hyperglycemia is linked with low muscle function $[63,108]$. There are many factors that contribute to muscle dysfunction in diabetes. Excessive intramyocellular lipid (IMCL) lowers muscle quality and could impair muscle function [109]. Increased IMCL is frequently observed in T1DM patients [110]. Especially, increased IMCL is associated with poor glycemic control evaluated by hemoglobin A1c (HbA1c) [111]. Accumulation of advanced glycation end-products, which are associated with persistent hyperglycemia [112], is also thought to contribute to low muscle function in T1DM patients [63]. In addition, it has been reported that hyperglycemia is linked with muscle atrophy via a WW domain containing E3 ubiquitin protein ligase 1 (WWP1)/Krüppel-like factor 15 (KLF15) pathway [113]. Hyperglycemia inhibits degradation of KLF15 via downregulation of WWP1 and increased KLF15 promotes proteolysis via upregulation of atrogin-1 and MuRF1 [113,114]. Moreover, hormones or cytokines that are related to skeletal muscle are altered in T1DM. Diabetic patients appear to have higher GC and IL-6 levels and both have catabolic effects [115-117]. Moreover, insulin-like growth factor-1 (IGF-1) which is well known for its contribution to skeletal muscle regeneration and development is decreased with an alteration of the IGFBP [118-120]. Recently, mitochondrial dysfunction in T1DM has been suggested as a primary contributor to muscle dysfunction. Mitochondrial changes in T1DM-related sarcopenia are similar to that in age-related ones, and both include elevated oxidative stress and mitochondrial-induced cell death [121]. LADA is a subtype of T1DM but has insulin resistance similar to type 2 diabetes mellitus (T2DM) [122]. LADA had a higher risk of sarcopenia as compared with controls and even T2DM groups in a cross-sectional study, but, so far, the association between LADA and sarcopenia has not been elucidated in great detail [64].

\section{Conclusions}

In this in-depth review, we provide evidence that sarcopenia is common in different autoimmune and rheumatic diseases. The exact prevalence differs among different studies, in part, due to the different definitions of sarcopenia that are used. We propose that reporting sarcopenia in autoimmune and rheumatic disorders is essential, since it contributes to morbidity and mortality among these patients. Specific risk factors need to be confirmed in larger studies with a particular focus on treatment strategies, i.e., cumulative dose of GC or other immunosuppressive measures. More detailed analyses highlighting the role of chronic inflammation in the propagation of sarcopenia are needed.

Supplementary Materials: Supplementary materials can be found at http:/www.mdpi.com/1422-0067/21/16/ 5678/s1, Table S1: Study findings of rheumatoid arthritis and sarcopenia, Table S2: Study findings of rheumatic diseases other than rheumatoid arthritis and sarcopenia, Table S3: Study findings of inflammatory bowel disease and sarcopenia.

Author Contributions: Conceptualization, J.I.S.; project administration, J.I.S. and K.H.L.; investigation, H.J.A.; writing-original draft preparation, H.J.A.; writing-review and editing, K.T., S.T., S.C., S.W.N., J.S.K., J.W.Y., J.Y.L., L.S., A.K. (Ai Koyanagi), L.J., H.L. and A.K. (Andreas Kronbichler); visualization, H.J.A.; supervision, J.I.S. and K.H.L. All authors have read and agreed to the published version of the manuscript.

Funding: This research received no external funding.

Conflicts of Interest: The authors declare no conflict of interest.

\section{Abbreviations}

ICD International Classification of Diseases

OR Odds ratio 


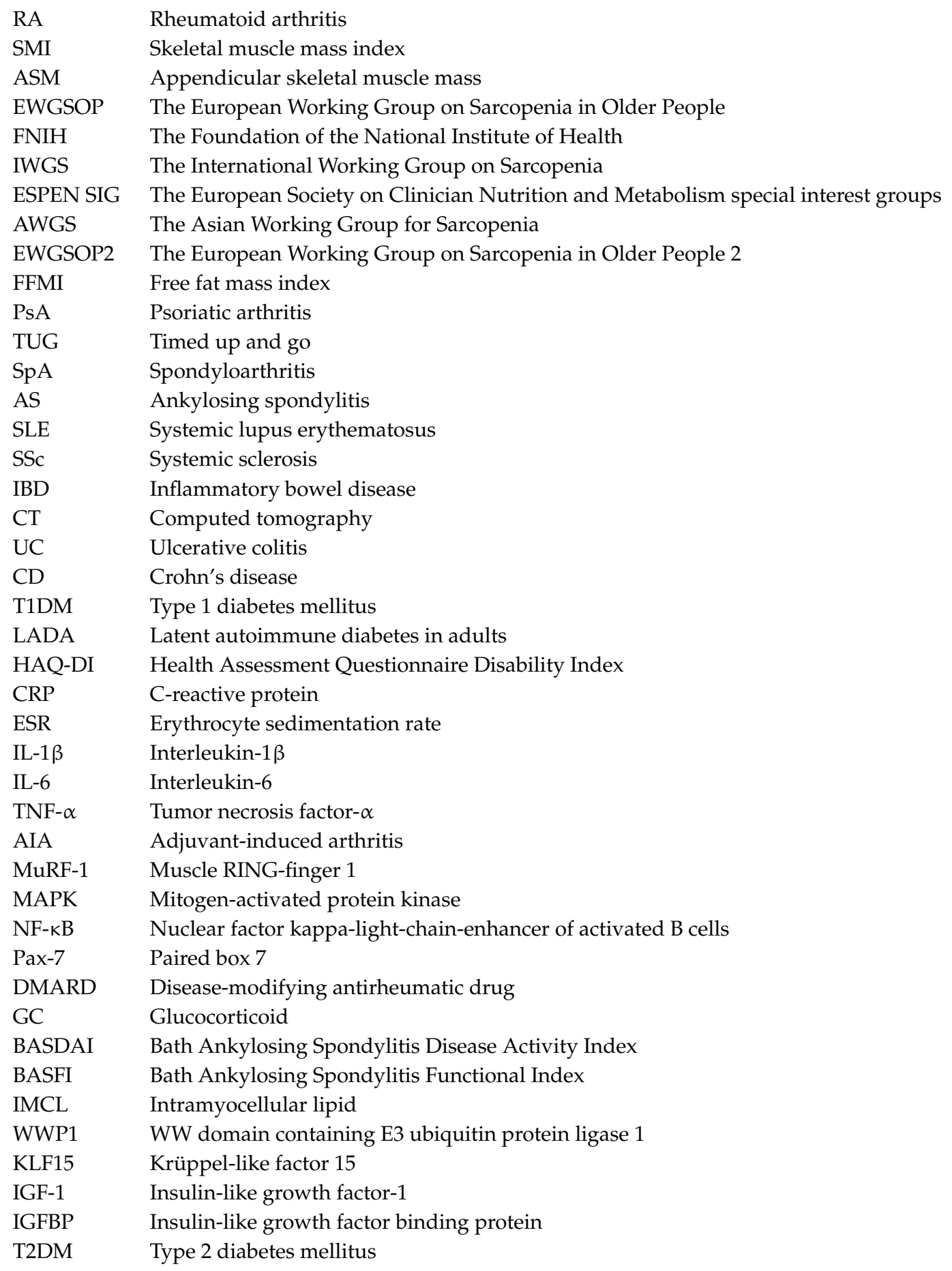

\section{References}

1. Doherty, T.J. Invited review: Aging and sarcopenia. J. Appl. Physiol. 2003, 95, 1717-1727. [CrossRef]

2. Rosenberg, I.H. Summary comments. Am. J. Clin. Nutr. 1989, 50, 1231-1233. [CrossRef]

3. Rosenberg, I.H. Sarcopenia: Origins and Clinical Relevance. J. Nutr. 1997, 127, 990S-991S. [CrossRef]

4. Cruz-Jentoft, A.J.; Baeyens, J.P.; Bauer, J.M.; Boirie, Y.; Cederholm, T.; Landi, F.; Martin, F.C.; Michel, J.P.; Rolland, Y.; Schneider, S.M.; et al. Sarcopenia: European consensus on definition and diagnosis. Age Ageing 2010, 39, 412-423. [CrossRef]

5. Brown, J.C.; Harhay, M.O.; Harhay, M.N. Sarcopenia and mortality among a population-based sample of community-dwelling older adults. J. Cachexia. Sarcopenia Muscle 2016, 290-298. [CrossRef] 
6. Morley, J.E.; Anker, S.D.; von Haehling, S. Prevalence, incidence, and clinical impact of sarcopenia: Facts, numbers, and epidemiology-Update 2014. J. Cachexia. Sarcopenia Muscle 2014, 5, 253-259. [CrossRef]

7. Sousa, A.S.; Guerra, R.S.; Fonseca, I.; Pichel, F.; Ferreira, S.; Amaral, T.F. Financial impact of sarcopenia on hospitalization costs. Eur. J. Clin. Nutr. 2016, 70, 1046-1051. [CrossRef] [PubMed]

8. Anker, S.D.; Morley, J.E.; von Haehling, S. Welcome to the ICD-10 code for sarcopenia. J. Cachexia. Sarcopenia Muscle 2016, 7, 512-514. [CrossRef] [PubMed]

9. Santilli, V.; Bernetti, A.; Mangone, M.; Paoloni, M. Clinical definition of sarcopenia. Clin. Cases Miner. Bone Metab. 2014, 11, 177-180. [CrossRef] [PubMed]

10. Ryall, J.G.; Schertzer, J.D.; Lynch, G.S. Cellular and molecular mechanisms underlying age-related skeletal muscle wasting and weakness. Biogerontology 2008, 9, 213-228. [CrossRef] [PubMed]

11. Michaud, M.; Balardy, L.; Moulis, G.; Gaudin, C.; Peyrot, C.; Vellas, B.; Cesari, M.; Nourhashemi, F. Proinflammatory cytokines, aging, and age-related diseases. J. Am. Med. Dir. Assoc. 2013, 14, 877-882. [CrossRef]

12. Jones, G.; Pilling, L.C.; Kuo, C.-L.; Kuchel, G.; Ferrucci, L.; Melzer, D. Sarcopenia and Variation in the Human Leukocyte Antigen Complex. J. Gerontol. A. Biol. Sci. Med. Sci. 2020, 75, 301-308. [CrossRef] [PubMed]

13. Baumgartner, R.N.; Koehler, K.M.; Gallagher, D.; Romero, L.; Heymstleld, S.B.; Ross, R.R.; Garry, P.J.; Lindeman, R.D. Epidemiology of Sarcopenia among the Elderly in New Mexico. Am J Epidemiol 1998, 147, 755-763. [CrossRef] [PubMed]

14. Janssen, I.; Baumgartner, R.N.; Ross, R.; Rosenberg, I.H.; Roubenoff, R. Skeletal muscle cutpoints associated with elevated physical disability risk in older men and women. Am J Epidemiol 2004, 159, 413-421. [CrossRef] [PubMed]

15. Studenski, S.A.; Peters, K.W.; Alley, D.E.; Cawthon, P.M.; McLean, R.R.; Harris, T.B.; Ferrucci, L.; Guralnik, J.M.; Fragala, M.S.; Kenny, A.M.; et al. The FNIH sarcopenia project: Rationale, study description, conference recommendations, and final estimates. J. Gerontol. A. Biol. Sci. Med. Sci. 2014, 69, 547-558. [CrossRef] [PubMed]

16. Fielding, R.A.; Vellas, B.; Evans, W.J.; Bhasin, S.; Morley, J.E.; Newman, A.B.; Abellan van Kan, G.; Andrieu, S.; Bauer, J.; Breuille, D.; et al. Sarcopenia: An Undiagnosed Condition in Older Adults. Current Consensus Definition: Prevalence, Etiology, and Consequences. International Working Group on Sarcopenia. J. Am. Med. Dir. Assoc. 2011, 12, 249-256. [CrossRef] [PubMed]

17. Muscaritoli, M.; Anker, S.D.; Argilés, J.; Aversa, Z.; Bauer, J.M.; Biolo, G.; Boirie, Y.; Bosaeus, I.; Cederholm, T.; Costelli, P.; et al. Consensus definition of sarcopenia, cachexia and pre-cachexia: Joint document elaborated by Special Interest Groups (SIG) " cachexia-anorexia in chronic wasting diseases" and " nutrition in geriatrics". Clin. Nutr. 2010, 29, 154-159. [CrossRef]

18. Chen, L.K.; Liu, L.K.; Woo, J.; Assantachai, P.; Auyeung, T.W.; Bahyah, K.S.; Chou, M.Y.; Chen, L.Y.; Hsu, P.S.; Krairit, O.; et al. Sarcopenia in Asia: Consensus report of the Asian working group for sarcopenia. J. Am. Med. Dir. Assoc. 2014, 15, 95-101. [CrossRef]

19. Cruz-Jentoft, A.J.; Bahat, G.; Bauer, J.; Boirie, Y.; Bruyère, O.; Cederholm, T.; Cooper, C.; Landi, F.; Rolland, Y.; Sayer, A.A.; et al. Sarcopenia: Revised European consensus on definition and diagnosis. Age Ageing 2019, 48, 16-31. [CrossRef]

20. Schaap, L.A.; van Schoor, N.M.; Lips, P.; Visser, M. Associations of Sarcopenia Definitions, and Their Components, with the Incidence of Recurrent Falling and Fractures: The Longitudinal Aging Study Amsterdam. J. Gerontol. A Biol. Sci. Med. Sci. 2018, 73, 1199-1204. [CrossRef]

21. Ibrahim, K.; May, C.; Patel, H.P.; Baxter, M.; Sayer, A.A.; Roberts, H. A feasibility study of implementing grip strength measurement into routine hospital practice (GRImP): Study protocol. Pilot Feasibility Stud. 2016, 2, 27. [CrossRef] [PubMed]

22. Leong, D.P.; Teo, K.K.; Rangarajan, S.; Lopez-Jaramillo, P.; Avezum, A.; Orlandini, A.; Seron, P.; Ahmed, S.H.; Rosengren, A.; Kelishadi, R.; et al. Prognostic value of grip strength: Findings from the Prospective Urban Rural Epidemiology (PURE) study. Lancet 2015, 386, 266-273. [CrossRef]

23. Schaap, L.A.; Koster, A.; Visser, M. Adiposity, muscle mass, and muscle strength in relation to functional decline in older persons. Epidemiol. Rev. 2013, 35, 51-65. [CrossRef] [PubMed]

24. Krajewska-Wlodarczyk, M.; Owczarczyk-Saczonek, A.; Placek, W. Changes in body composition and bone mineral density in postmenopausal women with psoriatic arthritis. Reumatologia 2017, 55, 215-221. [CrossRef] [PubMed] 
25. Janssen, I.; Heymsfield, S.B.; Ross, R. Low relative skeletal muscle mass (sarcopenia) in older persons is associated with functional impairment and physical disability. J. Am. Geriatr. Soc. 2002, 50, 889-896. [CrossRef]

26. Dao, H.H.; Do, Q.T.; Sakamoto, J. Abnormal body composition phenotypes in Vietnamese women with early rheumatoid arthritis. Rheumatology (Oxford) 2011, 50, 1250-1258. [CrossRef]

27. Hull, H.R.; Thornton, J.; Wang, J.; Pierson, R.N.; Kaleem, Z.; Pi-Sunyer, X.; Heymsfield, S.; Albu, J.; Fernandez, J.R.; Vanitallie, T.B.; et al. Fat-free mass index: Changes and race/ethnic differences in adulthood. Int. J. Obes. 2011, 35, 121-127. [CrossRef]

28. Santos, M.J.; Vinagre, F.; Canas Da Silva, J.; Gil, V.; Fonseca, J.E. Body composition phenotypes in systemic lupus erythematosus and rheumatoid arthritis: A comparative study of Caucasian female patients. Clin. Exp. Rheumatol. 2011, 29, 470-476.

29. Schutz, Y.; Kyle, U.U.G.; Pichard, C. Fat-free mass index and fat mass index percentiles in caucasians aged 189-8 y. Int. J. Obes. 2002, 26, 953-960. [CrossRef]

30. Giles, J.T.; Ling, S.M.; Ferrucci, L.; Bartlett, S.J.; Andersen, R.E.; Towns, M.; Muller, D.; Fontaine, K.R.; Bathon, J.M. Abnormal body composition phenotypes in older rheumatoid arthritis patients: Association with disease characteristics and pharmacotherapies. Arthritis Care Res. 2008, 59, 807-815. [CrossRef]

31. Ceyhan Dogan, S.; Hizmetli, S.; Hayta, E.; Kaptanoglu, E.; Erselcan, T.; Guler, E. Sarcopenia in women with rheumatoid arthritis. Eur. J. Rheumatol. 2015, 2, 57-61. [CrossRef] [PubMed]

32. Tournadre, A.; Pereira, B.; Dutheil, F.; Giraud, C.; Courteix, D.; Sapin, V.; Frayssac, T.; Mathieu, S.; Malochet-Guinamand, S.; Soubrier, M. Changes in body composition and metabolic profile during interleukin 6 inhibition in rheumatoid arthritis. J. Cachexia. Sarcopenia Muscle 2017, 8, 639-646. [CrossRef] [PubMed]

33. Lin, J.Z.; Liang, J.J.; Da Ma, J.; Li, Q.H.; Mo, Y.Q.; Cheng, W.M.; He, X.L.; Li, N.; Cao, M.H.; Xu, D.; et al. Myopenia is associated with joint damage in rheumatoid arthritis: A cross-sectional study. J. Cachexia. Sarcopenia Muscle 2019, 10, 355-367. [CrossRef] [PubMed]

34. Ngeuleu, A.; Allali, F.; Medrare, L.; Madhi, A.; Rkain, H.; Hajjaj-Hassouni, N. Sarcopenia in rheumatoid arthritis: Prevalence, influence of disease activity and associated factors. Rheumatol. Int. 2017, 37, 1015-1020. [CrossRef] [PubMed]

35. Tada, M.; Yamada, Y.; Mandai, K.; Hidaka, N. Matrix metalloprotease 3 is associated with sarcopenia in rheumatoid arthritis-Results from the CHIKARA study. Int. J. Rheum. Dis. 2018, 21, 1962-1969. [CrossRef] [PubMed]

36. Mochizuki, T.; Yano, K.; Ikari, K.; Okazaki, K. Sarcopenia-associated factors in Japanese patients with rheumatoid arthritis: A cross-sectional study. Geriatr. Gerontol. Int. 2019, 19, 907-912. [CrossRef] [PubMed]

37. Torii, M.; Hashimoto, M.; Hanai, A.; Fujii, T.; Furu, M.; Ito, H.; Uozumi, R.; Hamaguchi, M.; Terao, C.; Yamamoto, W.; et al. Prevalence and factors associated with sarcopenia in patients with rheumatoid arthritis. Mod. Rheumatol. 2019, 29, 589-595. [CrossRef] [PubMed]

38. Vlietstra, L.; Stebbings, S.; Meredith-Jones, K.; Haxby Abbott, J.; Treharne, G.J.; Waters, D.L. Sarcopenia in osteoarthritis and rheumatoid arthritis: The association with self-reported fatigue, physical function and obesity. PLoS ONE 2019, 14, e0217462. [CrossRef] [PubMed]

39. Barone, M.; Viggiani, M.; Anelli, M.; Fanizzi, R.; Lorusso, O.; Lopalco, G.; Cantarini, L.; Di Leo, A.; Lapadula, G.; Iannone, F. Sarcopenia in Patients with Rheumatic Diseases: Prevalence and Associated Risk Factors. J. Clin. Med. 2018, 7, 504. [CrossRef] [PubMed]

40. Lauretani, F.; Russo, C.R.; Bandinelli, S.; Bartali, B.; Cavazzini, C.; Di Iorio, A.; Corsi, A.M.; Rantanen, T.; Guralnik, J.M.; Ferrucci, L. Age-associated changes in skeletal muscles and their effect on mobility: An operational diagnosis of sarcopenia. J. Appl. Physiol. 2003, 95, 1851-1860. [CrossRef]

41. El Maghraoui, A.; Ebo'O, F.B.; Sadni, S.; Majjad, A.; Hamza, T.; Mounach, A. Is there a relation between pre-sarcopenia, sarcopenia, cachexia and osteoporosis in patients with ankylosing spondylitis? BMC Musculoskelet. Disord. 2016, 17, 268. [CrossRef] [PubMed]

42. Caimmi, C.; Caramaschi, P.; Venturini, A.; Bertoldo, E.; Vantaggiato, E.; Viapiana, O.; Ferrari, M.; Lippi, G.; Frulloni, L.; Rossini, M. Malnutrition and sarcopenia in a large cohort of patients with systemic sclerosis. Clin. Rheumatol. 2018, 37, 987-997. [CrossRef] [PubMed]

43. Siegert, E.; March, C.; Otten, L.; Makowka, A.; Preis, E.; Buttgereit, F.; Riemekasten, G.; Müller-Werdan, U.; Norman, K. Prevalence of sarcopenia in systemic sclerosis: Assessing body composition and functional disability in patients with systemic sclerosis. Nutrition 2018, 55-56, 51-55. [CrossRef] [PubMed] 
44. Corallo, C.; Fioravanti, A.; Tenti, S.; Pecetti, G.; Nuti, R.; Giordano, N. Sarcopenia in systemic sclerosis: The impact of nutritional, clinical, and laboratory features. Rheumatol. Int. 2019, 39, 1767-1775. [CrossRef] [PubMed]

45. Zhang, T.; Ding, C.; Xie, T.; Yang, J.; Dai, X.; Lv, T.; Li, Y.; Gu, L.; Wei, Y.; Gong, J.; et al. Skeletal muscle depletion correlates with disease activity in ulcerative colitis and is reversed after colectomy. Clin. Nutr. 2017, 36, 1586-1592. [CrossRef]

46. Fearon, K.; Strasser, F.; Anker, S.D.; Bosaeus, I.; Bruera, E.; Fainsinger, R.L.; Jatoi, A.; Loprinzi, C.; MacDonald, N.; Mantovani, G.; et al. Definition and classification of cancer cachexia: An international consensus. Lancet Oncol. 2011, 12, 489-495. [CrossRef]

47. Cushing, K.C.; Kordbacheh, H.; Gee, M.S.; Kambadakone, A.; Ananthakrishnan, A.N. Sarcopenia is a novel predictor of the need for rescue therapy in hospitalized ulcerative colitis patients. J. Crohn's Colitis 2018, 12, 1036-1041. [CrossRef]

48. Mager, D.R.; Carroll, M.W.; Wine, E.; Siminoski, K.; MacDonald, K.; Kluthe, C.L.; Medvedev, P.; Chen, M.; $\mathrm{Wu}$, J.; Turner, J.M.; et al. Vitamin D status and risk for sarcopenia in youth with inflammatory bowel diseases. Eur. J. Clin. Nutr. 2018, 72, 623-626. [CrossRef]

49. Webber, C.E.; Barr, R.D. Age and gender-dependent values of skeletal muscle mass in healthy children and adolescents. J. Cachexia. Sarcopenia Muscle 2012, 3, 25-29. [CrossRef]

50. Bamba, S.; Sasaki, M.; Takaoka, A.; Takahashi, K.; Imaeda, H.; Nishida, A.; Inatomi, O.; Sugimoto, M.; Andoh, A. Sarcopenia is a predictive factor for intestinal resection in admitted patients with Crohn's disease. PLoS ONE 2017, 12, e0180036. [CrossRef]

51. Nishikawa, H.; Shiraki, M.; Hiramatsu, A.; Moriya, K.; Hino, K.; Nishiguchi, S. Japan Society of Hepatology guidelines for sarcopenia in liver disease (1st edition): Recommendation from the working group for creation of sarcopenia assessment criteria. Hepatol. Res. 2016, 46, 951-963. [CrossRef] [PubMed]

52. Adams, D.W.; Gurwara, S.; Silver, H.J.; Horst, S.N.; Beaulieu, D.B.; Schwartz, D.A.; Seidner, D.L. Sarcopenia Is Common in Overweight Patients with Inflammatory Bowel Disease and May Predict Need for Surgery. Inflamm. Bowel Dis. 2017, 23, 1182-1186. [CrossRef] [PubMed]

53. Prado, C.M.; Lieffers, J.R.; McCargar, L.J.; Reiman, T.; Sawyer, M.B.; Martin, L.; Baracos, V.E. Prevalence and clinical implications of sarcopenic obesity in patients with solid tumours of the respiratory and gastrointestinal tracts: A population-based study. Lancet Oncol. 2008, 9, 629-635. [CrossRef]

54. Zhang, T.; Cao, L.; Cao, T.; Yang, J.; Gong, J.; Zhu, W.; Li, N.; Li, J. Prevalence of Sarcopenia and Its Impact on Postoperative Outcome in Patients with Crohn's Disease Undergoing Bowel Resection. J. Parenter. Enter. Nutr. 2017, 41, 592-600. [CrossRef] [PubMed]

55. O'Brien, S.; Kavanagh, R.G.; Carey, B.W.; Maher, M.M.; O'Connor, O.J.; Andrews, E.J. The impact of sarcopenia and myosteatosis on postoperative outcomes in patients with inflammatory bowel disease. Eur. Radiol. Exp. 2018, 2, 37. [CrossRef] [PubMed]

56. Martin, L.; Birdsell, L.; MacDonald, N.; Reiman, T.; Clandinin, M.T.; McCargar, L.J.; Murphy, R.; Ghosh, S.; Sawyer, M.B.; Baracos, V.E. Cancer cachexia in the age of obesity: Skeletal muscle depletion is a powerful prognostic factor, independent of body mass index. J. Clin. Oncol. 2013, 31, 1539-1547. [CrossRef] [PubMed]

57. Thiberge, C.; Charpentier, C.; Gillibert, A.; Modzelewski, R.; Dacher, J.-N.; Savoye, G.; Savoye-Collet, C. Lower Subcutaneous or Visceral Adiposity Assessed by Abdominal Computed Tomography Could Predict Adverse Outcome in Patients With Crohn's Disease. J. Crohns. Colitis 2018, 12, 1429-1437. [CrossRef]

58. Mourtzakis, M.; Prado, C.M.M.; Lieffers, J.R.; Reiman, T.; McCargar, L.J.; Baracos, V.E. A practical and precise approach to quantification of body composition in cancer patients using computed tomography images acquired during routine care. Appl. Physiol. Nutr. Metab. 2008, 33, 997-1006. [CrossRef]

59. Lee, C.H.; Yoon, H.; Oh, D.J.; Lee, J.M.; Choi, Y.J.; Shin, C.M.; Park, Y.S.; Kim, N.; Lee, D.H.; Kim, J.S. The prevalence of sarcopenia and its effect on prognosis in patients with Crohn's disease. Intest. Res. 2020, 18, 79-84. [CrossRef]

60. Kim, Y.S.; Lee, Y.; Chung, Y.S.; Lee, D.-J.; Joo, N.S.; Hong, D.; Song, G.E.; Kim, H.J.; Choi, Y.J.; Kim, K.M. Prevalence of sarcopenia and sarcopenic obesity in the Korean population based on the Fourth Korean National Health and Nutritional Examination Surveys. J. Gerontol. A. Biol. Sci. Med. Sci. 2012, 67, 1107-1113. [CrossRef] 
61. Cravo, M.L.; Velho, S.; Torres, J.; Costa Santos, M.P.; Palmela, C.; Cruz, R.; Strecht, J.; Maio, R.; Baracos, V. Lower skeletal muscle attenuation and high visceral fat index are associated with complicated disease in patients with Crohn's disease: An exploratory study. Clin. Nutr. ESPEN 2017, 21, 79-85. [CrossRef] [PubMed]

62. Carvalho, D.; Viana, C.; Marques, I.; Costa, C.; Martins, S.F. Sarcopenia is associated with Postoperative Outcome in Patients with Crohn's Disease Undergoing Bowel Resection. Gastrointest. Disord. 2019, 1, 15. [CrossRef]

63. Mori, H.; Kuroda, A.; Araki, M.; Suzuki, R.; Taniguchi, S.; Tamaki, M.; Akehi, Y.; Matsuhisa, M. Advanced glycation end-products are a risk for muscle weakness in Japanese patients with type 1 diabetes. J. Diabetes Investig. 2017, 8, 377-382. [CrossRef] [PubMed]

64. Bouchi, R.; Fukuda, T.; Takeuchi, T.; Nakano, Y.; Murakami, M.; Minami, I.; Izumiyama, H.; Hashimoto, K.; Yoshimoto, T.; Ogawa, Y. Association of sarcopenia with both latent autoimmune diabetes in adults and type 2 diabetes: A cross-sectional study. J. Diabetes Complicat. 2017, 31, 992-996. [CrossRef] [PubMed]

65. Montano-Loza, A.J.; Angulo, P.; Meza-Junco, J.; Prado, C.M.M.; Sawyer, M.B.; Beaumont, C.; Esfandiari, N.; Ma, M.; Baracos, V.E. Sarcopenic obesity and myosteatosis are associated with higher mortality in patients with cirrhosis. J. Cachexia. Sarcopenia Muscle 2016, 7, 126-135. [CrossRef] [PubMed]

66. Roubenoff, R.; Roubenoff, R.A.; Cannon, J.G.; Kehayias, J.J.; Zhuang, H.; Dawson-Hughes, B.; Dinarello, C.A.; Rosenberg, I.H. Rheumatoid cachexia: Cytokine-driven hypermetabolism accompanying reduced body cell mass in chronic inflammation. J. Clin. Investig. 1994, 93, 2379-2386. [CrossRef]

67. Santo, R.C.E.; Fernandes, K.Z.; Lora, P.S.; Filippin, L.I.; Xavier, R.M. Prevalence of rheumatoid cachexia in rheumatoid arthritis: A systematic review and meta-analysis. J. Cachexia. Sarcopenia Muscle 2018, 9, 816-825. [CrossRef]

68. Munro, R.; Capell, H. Prevalence of low body mass in rheumatoid arthritis: Association with the acute phase response. Ann. Rheum. Dis. 1997, 56, 326-329. [CrossRef]

69. Kasher, M.; Gabdulina, G.; Beissebayeva, A.; Mussabaeva, D.; Tokarev, A.; Sarssenbayeva, M.; Omarova, K.; Mominova, G.; Livshits, G. Rheumatoid arthritis is associated with exacerbated body composition deterioration in Kazakh females. Nutrition 2019, 66, 219-226. [CrossRef]

70. Delgado-Frías, E.; González-Gay, M.A.; Muñiz-Montes, J.R.; Gómez Rodríguez-Bethencourt, M.A.; González-Díaz, A.; Díaz-González, F.; Ferraz-Amaro, I. Relationship of abdominal adiposity and body composition with endothelial dysfunction in patients with rheumatoid arthritis. Clin. Exp. Rheumatol. 2015, 33, 516-523.

71. Bruce, B.; Fries, J.F. The Stanford Health Assessment Questionnaire: Dimensions and practical applications. Health Qual. Life Outcomes 2003, 1, 20. [CrossRef] [PubMed]

72. Müller, R.; Kull, M.; Põlluste, K.; Valner, A.; Lember, M.; Kallikorm, R. Factors associated with low lean mass in early rheumatoid arthritis: A cross-sectional study. Med. 2019, 55, 730. [CrossRef] [PubMed]

73. Alkan Melıkoğlu, M. Presarcopenia and its impact on disability in female patients with rheumatoid arthritis. Arch. Rheumatol. 2017, 32, 53-59. [CrossRef] [PubMed]

74. Beenakker, K.G.M.; Ling, C.H.; Meskers, C.G.M.; de Craen, A.J.M.; Stijnen, T.; Westendorp, R.G.J.; Maier, A.B. Patterns of muscle strength loss with age in the general population and patients with a chronic inflammatory state. Ageing Res. Rev. 2010, 9, 431-436. [CrossRef] [PubMed]

75. Fenton, C.G.; Webster, J.M.; Martin, C.S.; Fareed, S.; Wehmeyer, C.; MacKie, H.; Jones, R.; Seabright, A.P.; Lewis, J.W.; Lai, Y.C.; et al. Therapeutic glucocorticoids prevent bone loss but drive muscle wasting when administered in chronic polyarthritis. Arthritis Res. Ther. 2019, 21, 182. [CrossRef]

76. Yamada, Y.; Tada, M.; Mandai, K.; Hidaka, N.; Inui, K.; Nakamura, H. Glucocorticoid use is an independent risk factor for developing sarcopenia in patients with rheumatoid arthritis: From the CHIKARA study. Clin. Rheumatol. 2020. [CrossRef]

77. Gómez-SanMiguel, A.B.; Gomez-Moreira, C.; Nieto-Bona, M.P.; Fernández-Galaz, C.; Villanúa, M.Á.; Martín, A.I.; López-Calderón, A. Formoterol decreases muscle wasting as well as inflammation in the rat model of rheumatoid arthritis. Am. J. Physiol.—Endocrinol. Metab. 2016, 310, E925-E937. [CrossRef]

78. Yamada, T.; Abe, M.; Lee, J.; Tatebayashi, D.; Himori, K.; Kanzaki, K.; Wada, M.; Bruton, J.D.; Westerblad, H.; Lanner, J.T. Muscle dysfunction associated with adjuvant-induced arthritis is prevented by antioxidant treatment. Skelet. Muscle 2015, 5, 20. [CrossRef] 
79. Himori, K.; Tatebayashi, D.; Kanzaki, K.; Wada, M.; Westerblad, H.; Lanner, J.T.; Yamada, T. Neuromuscular electrical stimulation prevents skeletal muscle dysfunction in adjuvant-induced arthritis rat. PLoS ONE 2017, 12, e0179925. [CrossRef]

80. Little, R.D.; Prieto-Potin, I.; Pérez-Baos, S.; Villalvilla, A.; Gratal, P.; Cicuttini, F.; Largo, R.; Herrero-Beaumont, G. Compensatory anabolic signaling in the sarcopenia of experimental chronic arthritis. Sci. Rep. 2017, 7, 6311. [CrossRef]

81. Visser, M.; Pahor, M.; Taaffe, D.R.; Goodpaster, B.H.; Simonsick, E.M.; Newman, A.B.; Nevitt, M.; Harris, T.B. Relationship of interleukin- 6 and tumor necrosis factor-alpha with muscle mass and muscle strength in elderly men and women: The Health ABC Study. J. Gerontol. A Biol. Sci. Med. Sci. 2002, 57, M326-M332. [CrossRef] [PubMed]

82. Castillero, E.; Martín, A.I.; López-Menduiña, M.; Granado, M.; Villanúa, M.Á.; López-Calderón, A. IGF-I system, atrogenes and myogenic regulatory factors in arthritis induced muscle wasting. Mol. Cell. Endocrinol. 2009, 309, 8-16. [CrossRef] [PubMed]

83. de Oliveira Nunes Teixeira, V.; Filippin, L.I.; Viacava, P.R.; de Oliveira, P.G.; Xavier, R.M. Muscle wasting in collagen-induced arthritis and disuse atrophy. Exp. Biol. Med. 2013, 238, 1421-1430. [CrossRef] [PubMed]

84. Li, W.; Moylan, J.S.; Chambers, M.A.; Smith, J.; Reid, M.B. Interleukin-1 stimulates catabolism in $\mathrm{C}_{2} \mathrm{C}_{12}$ myotubes. Am. J. Physiol.—Cell Physiol. 2009, 297, 706-714. [CrossRef] [PubMed]

85. Garg, N.; Van Den Bosch, F.; Deodhar, A. The concept of spondyloarthritis: Where are we now? Best Pract. Res. Clin. Rheumatol. 2014, 28, 663-672. [CrossRef] [PubMed]

86. Aguiar, R.; Sequeira, J.; Meirinhos, T.; Ambrósio, C.; Barcelos, A. SARCOSPA-sarcopenia in spondyloarthritis patients. Acta Reumatol. Port. 2014, 2014, 322-326.

87. Pacini, G.; Paolino, S.; C Trombetta, A.; Goegan, F.; Pizzorni, C.; Alessandri, E.; Patanè, M.; Gotelli, E.; Ferrari, G.; Cattelan, F.; et al. Lower urinary tract symptoms in systemic sclerosis: A detailed investigation. Rheumatology (Oxford) 2020, 59, 1315-1324. [CrossRef]

88. Justo, A.C.; Guimarães, F.S.; Ferreira, A.S.; Soares, M.S.; Bunn, P.S.; Lopes, A.J. Muscle function in women with systemic sclerosis: Association with fatigue and general physical function. Clin. Biomech. 2017, 47, 33-39. [CrossRef]

89. Marighela, T.F.; Genaro, P.D.S.; Pinheiro, M.M.; Szejnfeld, V.L.; Kayser, C. Risk factors for body composition abnormalities in systemic sclerosis. Clin. Rheumatol. 2013, 32, 1037-1044. [CrossRef]

90. Ross, L.; Stevens, W.; Rabusa, C.; Wilson, M.; Ferdowsi, N.; Walker, J.; Sahhar, J.; Ngian, G.S.; Zochling, J.; Roddy, J.; et al. The role of inflammatory markers in assessment of disease activity in systemic sclerosis. Clin. Exp. Rheumatol. 2018, 36, S126-S134.

91. Walker, U.A.; Clements, P.J.; Allanore, Y.; Distler, O.; Oddis, C.V.; Khanna, D.; Furst, D.E. Muscle involvement in systemic sclerosis: Points to consider in clinical trials. Rheumatology (Oxford) 2017, 56, v38-v44. [CrossRef] [PubMed]

92. König, M.; Spira, D.; Demuth, I.; Steinhagen-Thiessen, E.; Norman, K. Polypharmacy as a Risk Factor for Clinically Relevant Sarcopenia: Results from the Berlin Aging Study II. J. Gerontol. A Biol. Sci. Med. Sci. 2017, 73, 117-122. [CrossRef] [PubMed]

93. Doerfler, B.; Allen, T.S.; Southwood, C.; Brenner, D.; Hirano, I.; Sheean, P. Medical Nutrition Therapy for Patients with Advanced Systemic Sclerosis (MNT PASS): A Pilot Intervention Study. J. Parenter. Enter. Nutr. 2017, 41, 678-684. [CrossRef] [PubMed]

94. Wen, Z.; Fiocchi, C. Inflammatory bowel disease: Autoimmune or immune-mediated pathogenesis? Clin. Dev. Immunol. 2004, 11, 195-204. [CrossRef]

95. Zhang, Y.Z.; Li, Y.Y. Inflammatory bowel disease: Pathogenesis. World J. Gastroenterol. 2014, 20, 91-99. [CrossRef]

96. Ryan, E.; McNicholas, D.; Creavin, B.; Kelly, M.E.; Walsh, T.; Beddy, D. Sarcopenia and Inflammatory Bowel Disease: A Systematic Review. Inflamm. Bowel Dis. 2019, 25, 67-73. [CrossRef]

97. Bryant, R.V.; Schultz, C.G.; Ooi, S.; Goess, C.; Costello, S.P.; Vincent, A.D.; Schoeman, S.N.; Lim, A.; Bartholomeusz, F.D.; Travis, S.P.L.; et al. Obesity in inflammatory bowel disease: Gains in adiposity despite high prevalence of Myopenia and Osteopenia. Nutrients 2018, 10, 1192. [CrossRef]

98. Pedersen, M.; Cromwell, J.; Nau, P. Sarcopenia is a Predictor of Surgical Morbidity in Inflammatory Bowel Disease. Inflamm. Bowel Dis. 2017, 23, 1867-1872. [CrossRef] 
99. Fujikawa, H.; Araki, T.; Okita, Y.; Kondo, S.; Kawamura, M.; Hiro, J.; Toiyama, Y.; Kobayashi, M.; Tanaka, K.; Inoue, Y.; et al. Impact of sarcopenia on surgical site infection after restorative proctocolectomy for ulcerative colitis. Surg. Today 2017, 47, 92-98. [CrossRef]

100. Ding, N.S.; Malietzis, G.; Lung, P.F.C.; Penez, L.; Yip, W.M.; Gabe, S.; Jenkins, J.T.; Hart, A. The body composition profile is associated with response to anti-TNF therapy in Crohn's disease and may offer an alternative dosing paradigm. Aliment. Pharmacol. Ther. 2017, 46, 883-891. [CrossRef]

101. Aubrey, J.; Esfandiari, N.; Baracos, V.E.; Buteau, F.A.; Frenette, J.; Putman, C.T.; Mazurak, V.C. Measurement of skeletal muscle radiation attenuation and basis of its biological variation. Acta Physiol. 2014, 210, 489-497. [CrossRef] [PubMed]

102. Werkstetter, K.J.; Ullrich, J.; Schatz, S.B.; Prell, C.; Koletzko, B.; Koletzko, S. Lean body mass, physical activity and quality of life in paediatric patients with inflammatory bowel disease and in healthy controls. J. Crohns. Colitis 2012, 6, 665-673. [CrossRef] [PubMed]

103. Kostic, A.D.; Xavier, R.J.; Gevers, D. The microbiome in inflammatory bowel disease: Current status and the future ahead. Gastroenterology 2014, 146, 1489-1499. [CrossRef] [PubMed]

104. Bindels, L.B.; Delzenne, N.M. Muscle wasting: The gut microbiota as a new therapeutic target? Int. J. Biochem. Cell Biol. 2013, 45, 2186-2190. [CrossRef]

105. Bindels, L.B.; Beck, R.; Schakman, O.; Martin, J.C.; de Backer, F.; Sohet, F.M.; Dewulf, E.M.; Pachikian, B.D.; Neyrinck, A.M.; Thissen, J.P.; et al. Restoring specific lactobacilli levels decreases inflammation and muscle atrophy markers in an acute leukemia mouse model. PLoS ONE 2012, 7, e37971. [CrossRef]

106. Subramaniam, K.; Fallon, K.; Ruut, T.; Lane, D.; McKay, R.; Shadbolt, B.; Ang, S.; Cook, M.; Platten, J.; Pavli, P.; et al. Infliximab reverses inflammatory muscle wasting (sarcopenia) in Crohn's disease. Aliment. Pharmacol. Ther. 2015, 41, 419-428. [CrossRef]

107. Katsarou, A.; Gudbjörnsdottir, S.; Rawshani, A.; Dabelea, D.; Bonifacio, E.; Anderson, B.J.; Jacobsen, L.M.; Schatz, D.A.; Lernmark, A. Type 1 diabetes mellitus. Nat. Rev. Dis. Prim. 2017, 3, 17016. [CrossRef]

108. Kalyani, R.R.; Metter, E.J.; Egan, J.; Golden, S.H.; Ferrucci, L. Hyperglycemia predicts persistently lower muscle strength with aging. Diabetes Care 2015, 38, 82-90. [CrossRef]

109. Choi, S.J.; Files, D.C.; Zhang, T.; Wang, Z.-M.; Messi, M.L.; Gregory, H.; Stone, J.; Lyles, M.F.; Dhar, S.; Marsh, A.P.; et al. Intramyocellular Lipid and Impaired Myofiber Contraction in Normal Weight and Obese Older Adults. J. Gerontol. A Biol. Sci. Med. Sci. 2016, 71, 557-564. [CrossRef]

110. Ebeling, P.; Essén-Gustavsson, B.; Tuominen, J.A.; Koivisto, V.A. Intramuscular triglyceride content is increased in IDDM. Diabetologia 1998, 41, 111-115. [CrossRef]

111. Perseghin, G.; Lattuada, G.; Danna, M.; Sereni, L.P.; Maffi, P.; De Cobelli, F.; Battezzati, A.; Secchi, A.; Del Maschio, A.; Luzi, L. Insulin resistance, intramyocellular lipid content, and plasma adiponectin in patients with type 1 diabetes. Am. J. Physiol.-Endocrinol. Metab. 2003, 285, E1174-E1181. [CrossRef] [PubMed]

112. Dyer, D.G.; Dunn, J.A.; Thorpe, S.R.; Lyons, T.J.; Mccance, D.R.; Baynes, J.W. Accumulation of Maillard Reaction Products in Skin Collagen in Diabetes and Aging. Ann. N. Y. Acad. Sci. 1992, 663, 421-422. [CrossRef] [PubMed]

113. Hirata, Y.; Nomura, K.; Senga, Y.; Okada, Y.; Kobayashi, K.; Okamoto, S.; Minokoshi, Y.; Imamura, M.; Takeda, S.; Hosooka, T.; et al. Hyperglycemia induces skeletal muscle atrophy via a WWP1/KLF15 axis. JCI insight 2019, 4, e124952. [CrossRef] [PubMed]

114. Shimizu, N.; Yoshikawa, N.; Ito, N.; Maruyama, T.; Suzuki, Y.; Takeda, S.I.; Nakae, J.; Tagata, Y.; Nishitani, S.; Takehana, K.; et al. Crosstalk between glucocorticoid receptor and nutritional sensor mTOR in skeletal muscle. Cell Metab. 2011, 13, 170-182. [CrossRef]

115. Roy, M.; Collier, B.; Roy, A. Hypothalamic-pituitary-adrenal axis dysregulation among diabetic outpatients. Psychiatry Res. 1990, 31, 31-37. [CrossRef]

116. Galassetti, P.R.; Iwanaga, K.; Crisostomo, M.; Zaldivar, F.P.; Larson, J.; Pescatello, A. Inflammatory cytokine, growth factor and counterregulatory responses to exercise in children with type 1 diabetes and healthy controls. Pediatr. Diabetes 2006, 7, 16-24. [CrossRef]

117. Muñoz-Cánoves, P.; Scheele, C.; Pedersen, B.K.; Serrano, A.L. Interleukin-6 myokine signaling in skeletal muscle: A double-edged sword? FEBS J. 2013, 280, 4131-4148. [CrossRef]

118. Wȩdrychowicz, A.; Dziatkowiak, H.; Nazim, J.; Sztefko, K. Insulin-like growth factor-1 and its binding proteins, IGFBP-1 and IGFBP-3, in adolescents with type-1 diabetes mellitus and microalbuminuria. Horm. Res. 2005, 63, 245-251. [CrossRef] 
119. Jehle, P.M.; Jehle, D.R.; Mohan, S.; Böhm, B.O. Serum levels of insulin-like growth factor system components and relationship to bone metabolism in type 1 and type 2 diabetes mellitus patients. J. Endocrinol. 1998, 159, 297-306. [CrossRef]

120. Sharma, A.; Purohit, S.; Sharma, S.; Bai, S.; Zhi, W.; Ponny, S.R.; Hopkins, D.; Steed, L.; Bode, B.; Anderson, S.W.; et al. IGF-binding proteins in type-1 diabetes are more severely altered in the presence of complications. Front. Endocrinol. (Lausanne) 2016, 7, 2. [CrossRef]

121. Monaco, C.M.F.; Gingrich, M.A.; Hawke, T.J. Considering Type 1 Diabetes as a Form of Accelerated Muscle Aging. Exerc. Sport Sci. Rev. 2019, 47, 98-107. [CrossRef] [PubMed]

122. Laugesen, E.; Østergaard, J.A.; Leslie, R.D. Latent Autoimmune Diabetes of the Adult. Diabet. Med. 2015, 32, 843-852. [CrossRef] [PubMed]

(C) 2020 by the authors. Licensee MDPI, Basel, Switzerland. This article is an open access article distributed under the terms and conditions of the Creative Commons Attribution (CC BY) license (http://creativecommons.org/licenses/by/4.0/). 